\title{
Natural Regeneration on Planted Clearcuts-The Easy Way to Mixed Forest?
}

\author{
Emma Holmström1 ${ }^{*}$, Per Magnus Ekö1, Karin Hjelm², Matts Karlsson', Urban Nilsson1 \\ ${ }^{1}$ Southern Swedish Forest Research Centre, Swedish University of Agricultural Science, Alnarp, Sweden \\ ${ }^{2}$ Skogforsk, Svalöv, Sweden \\ Email: *Emma.Holmstrom@slu.se
}

Received 22 June 2016; accepted 11 July 2016; published 14 July 2016

Copyright (C) 2016 by authors and Scientific Research Publishing Inc.

This work is licensed under the Creative Commons Attribution International License (CC BY).

http://creativecommons.org/licenses/by/4.0/

(c) $\underset{\mathrm{EY}}{\mathrm{i}}$ Open Access

\begin{abstract}
Establishing mixed stands by stimulating natural in combination with planting could potentially ensure adequate stocking and meet shifting demands for forest products. Two long-term experiments were separately established in former Norway spruce (Picea abies L. Karst) stands in southern Sweden to be able to evaluate mixed forest establishment and management. The treatment plots were treated with different intensity of soil scarification (disc trenching, soil inversion and control) to test effects of soil disturbance on regeneration success. Five years later, both experiments were used for a first evaluation, where seedlings of all naturally regenerated tree species were counted together with estimates of the cover and height of other vegetation. This was made in sample plots in symmetric grids. Testing the effects of scarification and distance to seed source on natural regeneration of silver birch (Betula pendula Roth.) and downy birch (B. pubescens Ehrh.) showed that both scarification type and degree of soil disturbance significantly affected seedling counts but only if seed sources were close. In conclusion, conventional management practices for regenerating coniferous forest may be suitable for establishing mixed forest stands with combinations of planted and naturally regenerated seedlings.
\end{abstract}

\section{Keywords}

Betula, Birch, Soil Scarification, Seed Dispersal

\section{Introduction}

In the clearcut forestry system, regeneration after harvesting is the starting point of future stands, and thus a primary determinant of their development and structure. Forests in Sweden are dominated by homogenous coniferous

\footnotetext{
"Corresponding author.
}

How to cite this paper: Holmström, E., Ekö, P. M., Hjelm, K., Karlsson, M., \& Nilsson, U. (2016). Natural Regeneration on Planted Clearcuts-The Easy Way to Mixed Forest? Open Journal of Forestry, 6, 281-294. 
stands for fast production of pulpwood and timber (Nilsson, 2013; Nilsson et al., 2011). Due to economic incentives, reinforced by binding clauses in the Swedish Forestry Act, more than $70 \%$ of the forest land in Sweden is currently regenerated by planting single conifer species at relatively high densities, between 2000 and 3000 seedlings per hectare, depending on site index and geographic location (Bergquist et al., 2011). However, increasing demand for biomass for energy (Paré et al., 2011) and increasing requests of sustainable management with a diversity of ecosystem services (Foley et al., 2005) call for modified forest practices with heterogeneous structures and mixed species stands (Bravo-Oviedo et al., 2014; Carnus et al., 2006; Hedwall et al., 2013; Knoke et al., 2008). Several studies have shown that converting coniferous monocultures to mixed stands can enhance the diversity and abundance of several taxa (Ammer et al., 2006; Chauvat et al., 2011) and change the soil properties within one rotation period (Hansson et al., 2011). Comparisons of Norway spruce monocultures and mixed stands with broadleaved species also show positive effect on other ecosystem services (Picea abies L. Karst) and biodiversity traits (Felton et al., 2011; Felton et al., 2010; Felton et al., 2016; Thelin et al., 2002).

To ensure sufficient seedling establishment and survival in Scandinavian coniferous plantations, soil scarification is required for several reasons. One important reason is that bare mineral soil surfaces around the seedling reduce feeding from the pine weevil (Hylobius abietis) (Petersson et al., 2005; Wallertz \& Petersson, 2011). Scarification also reduces competing vegetation which may be important for promoting growth in both height and basal area (Löf, 2000; Munson et al., 1993). Thus, soil scarification by various methods is used to control competing vegetation in countries where herbicide treatment is undesirable or restricted by law (Löf et al., 2012; Thiffault \& Roy, 2011). However, soil scarification also facilitates establishment of many seed-dispersed tree species (Clark et al., 2007; Johansson et al., 2013a). Differences between scarification techniques and proportion of soil surface disturbance might also influence the species composition of established communities (Newmaster et al., 2007). Similar to scarification, both clearcutting operations and storm felling can result in a disturbed soil that promotes seedling establishment (Dodet et al., 2011; Ilisson et al., 2007; Vodde et al., 2011; von Oheimb et al., 2007).

Slash removal, which is performed when the residues are sold to bioenergy companies, promotes establishment of naturally regenerated seedlings (Karlsson et al., 2002; Spracklen et al., 2013). Slash removal does not change the total aboveground vegetation biomass the following years after harvest but some species will be more abundant if branches and twigs are retained (Bergquist et al., 1999), including raspberry (Rubus idaeus) and, possibly, bracken (Pteridium aquilinum). Some strong competitors of water and nutrient, such as raspberry and willowherb (Chamerion angustifolium) are generally favored by retention of slash residues (Olsson \& Staaf, 1995 ) since the piles differ in nutrient and soil moisture conditions (Rosén \& Lundmark-Thelin, 1987). However, partly because of selective grazing and browsing, vegetation on conifer clearcuts in southern Sweden is dominated by a few species, notably wavy hair grass (Deschampsia flexuosa) that can account for up to $75 \%$ of the vegetative biomass (Bergquist et al., 1999).

Because clearcuts are normally scarified before planting, natural regeneration of the two native conifer tree species Norway spruce and Scots pine (Pinus sylvestris L.) as well as many broadleaved tree species frequently occurs on clearcuts. In southern Sweden the main broadleaved species are the two native birch species, silver birch and downy birch (Betula pubescens Ehrh). Both birch species are merchantable but silver birch is preferred (Betula pendula Roth) because of better production and for higher timber quality products. According to national forest inventory statistics, these species typically account for $80 \%$ of the naturally regenerated seedlings in forests during early rotation stages (Götmark et al., 2005). Other tree species that are frequently seed dispersed, and have varying potential commercial applications, include aspen (Populus tremula L.), rowan (Sorbus aucuparia L.), goat willow (Salix caprea L.), black alder (Alnus glutinosa L. Gaertner) and oak (Quercus Robur L.).

Seedlings that emerge and survive on clearcuts may originate from the seedbank or from dispersed seeds from adjacent stands. By cultivating seeds from forest soil seed banks, a Swedish study found that birch seeds have short survival periods (Granström \& Fries, 1985). Only 6\% of monitored seeds survived more than one season and many did not emerge until disturbance occurred. In a meta-analysis made on plant populations (Clark et al., 2007) the authors found seed limitation to be significant both in disturbed and undisturbed environments. The authors emphasized the need of handling seed limitation as a continuous variable in order to statistically evaluate the effects of establishment factors. Several studies have shown that only a limited amount of birch seeds falls more than 80 - 100 m from a forest edge (Fries, 1984; Greene \& Johnson, 1989; Karlsson, 2001; Spracklen et al., 2013). Karlsson (2001) also found a positive interaction between seed density and scarification on birch seedling emergence on three out of five sites. 
The increasing interest for admixtures of other tree species in the conifer plantations was the incitement to establish two long-term experiments where management of a planted crop species could be evaluated with and without admixture of the spontaneous natural regeneration. Both yield- and biodiversity-comparisons of mono versus polycultures are often evaluated either in a short period of time or on small scale level. Controlled experiments over a full rotation and on a stand level scale are obviously both time-consuming and expensive. However, the first step was to establish the potential mixtures. The experiments was situated in the southern part of Sweden where Norway spruce above is the most common planted tree species and Silver birch above the most abundant naturally regenerated tree. These experiments had to balance between several dimensions of duality of these two species; symmetrically planted seedlings against asymmetric natural regeneration, a shade tolerant species against a pioneer with fast establishment and initial growth, low pressure from ungulate browsers on planted Norway spruce against high browsing pressure on broadleaves and pine. One of the main objectives of the experiments was to mimic the conventional management and to test if small differences in regeneration treatments could have long lasting effect on stand composition. In this paper the regeneration treatments in these experiments were evaluated, regarding establishment of naturally regenerated seedlings and more specifically:

- Differences in establishment of naturally regenerated seedlings, primarily for birch, between soil scarification as traditional disc trenching and treatments resulting in lower rate of exposed bare mineral soil, i.e. soil inversion and control.

- Differences in abundance of field vegetation in sample plots and its correlation to scarification treatments and establishment of naturally regenerated seedlings.

- Correlation between distance to seed source and abundance of naturally regenerated seedlings.

\section{Materials and Methods}

\subsection{Experimental Design and Sites}

Two series of long term experiments were separately initiated 2006 with the intention to evaluate establishment, growth, species composition and yield of mixed forests on a stand level during the next stand rotation. One series was located in Kronoberg county and the other in Halland county, in southern Sweden between latitude $56^{\circ}$ and $58^{\circ} \mathrm{N}$ (Figure 1). Mean annual precipitation for the experimental sites in Kronoberg and Halland amounts to 657 and $1223 \mathrm{~mm} \cdot \mathrm{year}^{-1}$ respectively, and mean annual temperature of $7^{\circ} \mathrm{C}$. The treatments in both experiments were applied in randomized block designs on clearcuts of former Norway spruce monocultures felled after the major storm Gudrun in January 2005. All the selected clearcut sites had mesic till soils, site indecies ranging from G32 to G34, as defined by (Hägglund, 1977) and were surrounded by other coniferous stands. Some were close to sparse mixtures of broadleaves along neighboring brooks, ditches or wetlands but no broadleaf stands with mature trees were close to any of the borders. The blocks in Halland were closely located within a radius of $1 \mathrm{~km}$ apart while the blocks of Kronoberg were more dispersed, with a farthest distance of $27 \mathrm{~km}$. Only two blocks were located at the same site ( 2 and 3 ), in the Kronoberg experiment (Table 1). The experiment in Kronoberg had treatment plotsize of one hectare and in total four blocks. The experiment in Halland had three treatments (plotsize $0.1 \mathrm{ha}$ ) and in total three blocks.

Both experiments had soil scarification as one of the treatments in the establishment phase but also other future treatments planned further on in the stand development. Therefore, the layout of the soil scarification treatments was not balanced within the blocks (Table 1). However, both experiments had the same disc trenching (DT) technique included as the highest level of soil disturbance and were therefore chosen for this study. Disc trenching created continuous rows in $2 \mathrm{~m}$ distance. The humus layer, containing the present seed bank, was piled up in $10-30 \mathrm{~cm}$ high berms between the rows resulting in an estimated soil disturbance rate of $50 \%-60 \%$. The residual slash was aggregated into larger piles between the rows. In addition, the experiment in Kronoberg also included soil inversion (INV) or a combination of both (DT + INV). Soil inversion is a commercial scarification technique for planting patches with the soil inverted, created with excavators (Hallsby \& Orlander, 2004). The humus layer is turned upside down and covered by bare mineral soil. With soil inversion the target was to keep the soil surface flat. The number of patches with inverted soil in the treatments was aiming for 1000 patches ha $^{-1}$. The inverted patch was free from residual slash and the slash between patches was not piled up. The experiment in Halland had two treatments, either the disc trenching or no active soil scarification (NO). However, all of the clearcuts were on storm felled areas so the areas were not undisturbed at the soil surface. 


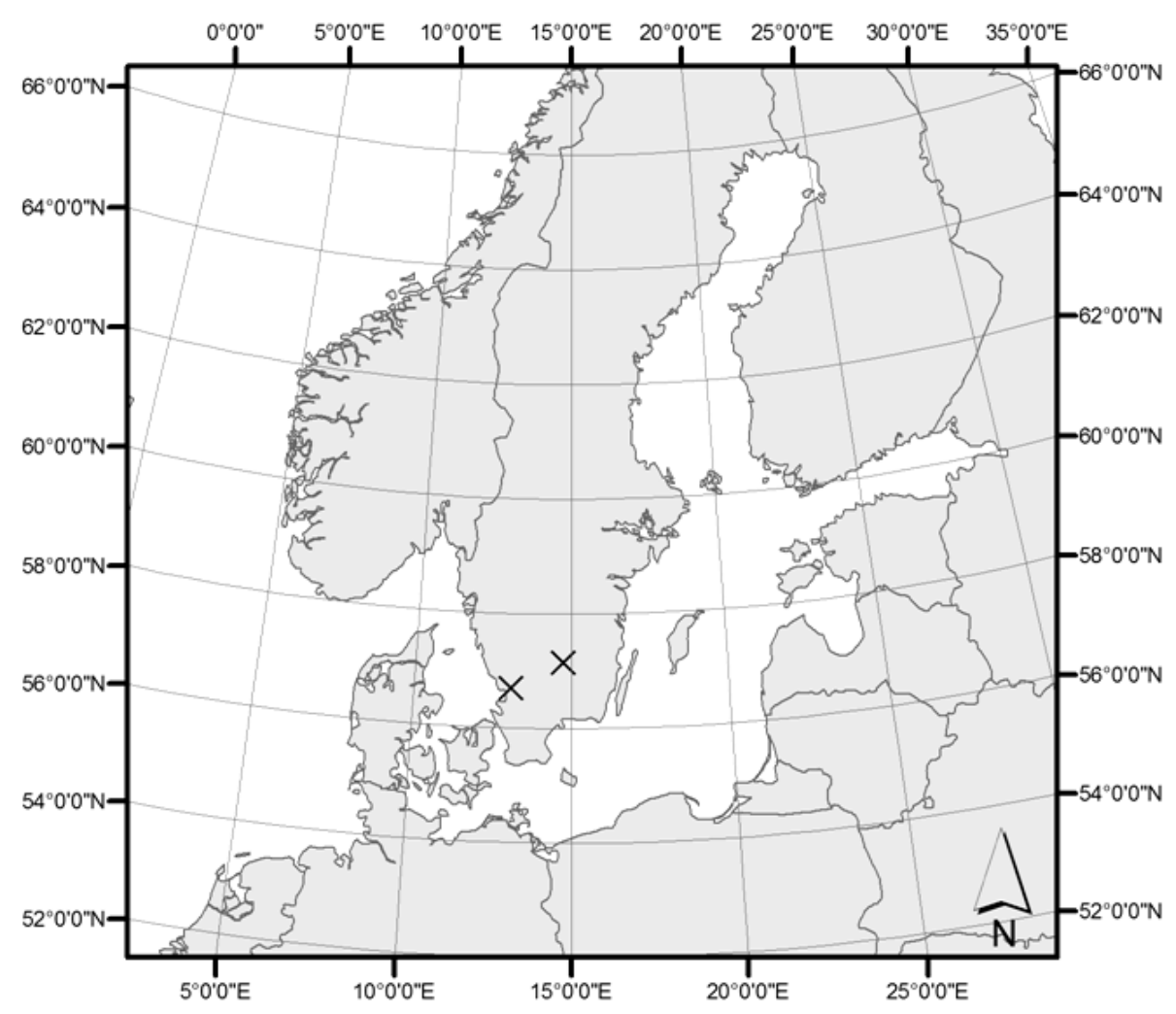

Figure 1. Location of experimental sites, Sweden.

Table 1. Number of treatment plots in each block in the two experiments in Kronoberg and Halland county. Soil scarification treatments are DT = disc trenching, INV = soil inversion and $\mathrm{No}=$ no active soil scarification. High and Low refer to the relative cover of soil disturbance in the treatments.

\begin{tabular}{cccccc}
\hline & & \multicolumn{3}{c}{ HiD } & \multicolumn{3}{c}{ LoD } \\
\cline { 3 - 6 } County & Block & DT & DT + INV & INV & No \\
\cline { 3 - 6 } Kronoberg & 1 & 2 & 1 & No. of treatment plots & \\
& 2 & 3 & 1 & 1 & \\
& 3 & 3 & 1 & 1 & 1 \\
\hline \multirow{3}{*}{ Halland } & 4 & 3 & & & 1 \\
& 12 & 2 & & & 1 \\
\hline
\end{tabular}

The estimated soil disturbance ratio for the low cover of soil disturbance, soil inversion in Kronoberg and no scarification in Halland, was $10 \%-30 \%$. Soil disturbance percentage was approximately $50 \%-60 \%$ in disc trenching treatments and $60 \%-70 \%$ in the combination of disc trenching and inverse treatments.

Planting was another treatment in the two long term experiments, however not in the scope of this study. In Kronoberg the planting density was either no, 1500 or 2800 seedlings $\cdot \mathrm{ha}^{-1}$ in the treatment plots, in Halland either no or 2800 seedlings $\cdot \mathrm{ha}^{-1}$. Both planting and soil scarification treatments were applied before the vegetation period, 2006 in Kronoberg and 2008 in Halland. 


\subsection{Regeneration Measurements}

During the autumn of 2011, a $10 \times 10 \mathrm{~m}$ systematic grid was laid out in the 1 ha treatment plots and a $5 \times 5 \mathrm{~m}$ systematic grid in the 0.1 ha treatment plots, with circular sample plots $(1 \mathrm{~m}$ radius $)$ at every node. The regeneration in the sample plots was then measured by counting individuals of each tree species, their height and damage were registered, together with the coverage of competing vegetation. The total area covered by the experiments was 20 ha and in total 2062 circular sample plots in 28 treatment plots were surveyed. The tree species recorded were all woody species that had the potential to reach canopy or subcanopy layer; Norway spruce, Scots pine, birch, aspen, rowan, oak wild cherry (Prunus avium L.), bird cherry (Prunus padus L.), goat willow, beech (Fagus sylvatica L.), black alder and hybrid larch (Larix x Eurolepis A). The two species of birch were counted separately but not divided in the data analyses.

The distance from seed source of each plot was calculated as the distance to the nearest clearcut edge in ArcGis 10.0 using GPS coordinates (approximate accuracy $0.2 \mathrm{~m}$ ) of the plots and stand borders obtained from field measurements and manual analysis of orthophotos provided by Lantmäteriet, the Swedish mapping, cadastral and land registration authority. GPS coordinates of all trees (diameter breast height $>10 \mathrm{~cm}$ ) at the clearcuts were recorded to complement estimates of distances to seed source in adjacent stands. At none of the clearcuts the amount of residual trees exceeded five trees per hectare. Most of the residual trees were birches but single occurrences of pine and rowan were present.

\subsection{Measurements of Ground Vegetation}

The percentage cover of vegetation in the plots was visually estimated using a nine-point scale starting with 0 (absent) and continuing with $12.5 \%$ increments, from $1(1 \%-12.5 \%)$ to $8(87.5 \%-100 \%)$. The cover of the following general groups of plant taxa was estimated separately: sub-layer, grasses, herbs, brackens, dwarf shrubs and shrubs, some of which were expected to correlate with tree regeneration success e.g., grass cover was expected to be negatively correlated with birch emergence and survival rates (Table 2). The total coverage could reach above $100 \%$ since there could be several layers of vegetation. In addition to the groups above, some species or functional groups have habitat preferences that correlate with characteristics of the microhabitats created by the specific soil scarification or storm damages. These traits were used, known a priori, to detect plot-specific traits of soil disturbance. The abundance of raspberry was used as an indicator of conditions hindering seedling emergence caused by piles of slash residues (Dodet et al., 2011; Nilsson et al., 2002; Olsson \& Staaf, 1995). The slash piles have a tendency to develop into clusters of nutrient high growth raspberry canes, probably due to raspberry seeds in the seedbank underneath the piles.

Five years after treatment the slash piles could be uncertain to estimate. In this case, the estimations of raspberry done in the plots were used to explain the empty plots with harsh conditions for seeds and seedlings during first year after treatment. The presence/absence of the moss genera Polytrichum and Sphagnum was recorded, in addition to total moss cover since their presence strongly correlates with long-term persistence of bare mineral soil or high soil moisture contents (Hallingbäck \& Tomas, 1996). The average height of the dominant vegetation in each of the plant groups was also estimated as an indication of their colonization rates. For every plot the area (using the cover scale for vegetation) unsuitable for regeneration due to the presence of large stones, large stumps and upturned roots after storm Gudrun, was estimated to adjust the plant cover estimates.

\subsection{Analytical Approach on Stand Level}

All statistical tests were performed in R 3.0 NLME package (R Core Team, 2013) to detect significant differences between means (at $\alpha=0.05$ ). Evaluation of residuals for the general linear models showed no violation of

Table 2. Average vegetation coverage (\%) in 1 m radius sample plots.
\begin{tabular}{cccccc}
\hline Soil Disturbance & Grasses & Raspberry & Dwarf shrubs & Herbs & Brackens \\
\hline HiD & $56 \%$ & $43 \%$ & $5 \%$ & $11 \%$ & $0 \%$ \\
LoD & $60 \%$ & $46 \%$ & $4 \%$ & $3 \%$ & $1 \%$ \\
\hline
\end{tabular}


assumptions for normality and constant variance. The effect of the soil scarification treatments (Treatments) on stand level was tested with a general linear model for the two experiments respectively (Table 1). Site was included with $\left(\right.$ Block $\left._{i}\right)$ as a fixed variable, $(i=1,2,3,4,12,45,86)$. The treatment effect was first tested with three levels in Kronoberg: DT, DT + INV and INV and two levels in Halland: DT and NO:

$$
\text { Stand.density }{ }_{\exp } \sim \alpha+\beta_{1} \text { Treatments }+\beta_{2} \text { Block }
$$

where Stand.density $\exp _{\text {was }}$ the densities of naturally regenerated seedlings $\cdot$ ha $^{-1}$ of all tree species in the two experiments (Table 1). In Kronoberg, as expected, the difference between DT and DT + INV was insignificant $(p$ $=0.743)$, but also the INV alone was not significantly different on stand level $(p=0.0589)$. In Halland the mean of the two DT treatments was not significantly different from the NO treatment plots in each block $(p=0.360)$. Therefore the effect of the cover of soil disturbance (SoilD) was tested for both experiments together. The treatments was grouped where high cover of soil disturbance (HiD) included disc trenching (DT, DT + INV) and tested against the more low cover (LoD) disturbance treatments (INV, NO).

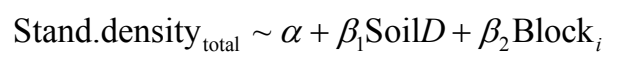

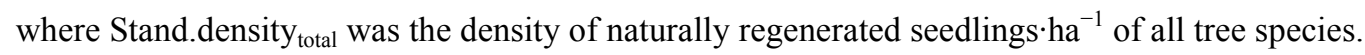

\subsection{Analytical Approach on Sample Plot Level}

A more thorough approach for evaluating regeneration responses was applied at sample plot level to adjust for two confounding variables, seed supply and spatial distribution. A model was constructed to test the effect of soil disturbance (SoilD) as a binary factor on birch seedling counts $Y_{j}$, where $j=1 \cdots 2061$. The level of soil disturbance was categorised as high (HiD) for all soil scarifications which included disc trenching or low (LoD) for scares methods such as inverse patches or for untreated areas. Increases in distance to seed sources are associated with reductions in probabilities of seeds falling in monitored plots and, consequently, reductions in treatment effects on natural regeneration. Thus, to adjust for spatial distribution and small-scale variation within the treatment plots, the distance to seed source (in meters, Dist $t_{j}$ ) was used as a continuous variable. Additionally, a correction for the effects of block, associated with geographic variation and forest structure in surrounding stands, was implemented, using a blocking factor $\left(\mathrm{Block}_{i}\right)$ and the interaction between block and scarification.

The acquired data were visually explored using Cleveland dotplots to detect outliers in variables, as well as box plots and interaction plots for factors, before further model testing (Zuur et al., 2010). The cover, height and occupancy (height multiplied by cover) of the defined functional plant groups were evaluated with both variance inflation factors (VIF < 3) and multipanel scatter plots to detect collinearity between covariates. Included in the exploration of the vegetation cover covariates was also the count of regenerated tree seedlings in the plot that was not birch, both naturally regenerated and planted. The model was simplified, as appropriate, when collinearity of variables was detected or when tests using the Drop 1 command in R indicated that they had non-significant effects. The final model of seedling counts included the counts of other regenerated tree seedlings $\left(\right.$ RegOther $\left._{j}\right)$, grass cover $\left(\right.$ Grass $\left._{j}\right)$, presence of the Sphagnum-Polytrichum group $\left(\right.$ Moss $\left._{j}\right)$ as a binary variable and the cover of raspberry multiplied by its height as a continuous variable estimating occupancy of the species in the plot $\left(R u b O c c_{j}\right)$. The latter two vegetation variables indicated earlier traces of soil disturbance and thus long-term treatment effects. Ground structure was not included since differences in the soil surface caused by disc trenching could not be accurately measured five years after scarification. The effects of these variables on birch seedlings $Y_{i}$ (Equation (3)) was tested in R 3.0 using a Poisson distribution with log link and the glm function in MASS package. An over dispersion of 3.25 was detected (dispersion parameter estimated as the deviance based on the sum of squares of the Pearson residuals divided by residual degrees of freedom) and further model testing was performed using a negative binomial distribution with a theta parameter $k=1.209$ to adjust for heterogeneity in the estimated variance (Hilbe \& Joseph, 2007). Dispersion parameter for the negative binomial family is taken to be 1 .

$$
\begin{aligned}
& \eta_{i, j} \sim \alpha+\beta_{1} \text { Dist }_{i j}+\beta_{2}{\text { Soil } D+\beta_{3} \text { Block }_{i}+\beta_{4}\left(\text { Soil } D * \text { Block }_{i}\right.} \\
&+\beta_{5} \text { Moss }_{j}+\beta_{6} \text { RubOcc }_{j}+\beta_{7} \text { Grass }_{j}+\beta_{8} \text { RegOther }_{j}
\end{aligned}
$$

where the response variable is distributed with estimated mean $\mu_{i, j}$ and parameter $k$ for the variance with intercept $\alpha$. $Y_{i, j} \sim N B\left(\mu_{i, j}, k\right)$, expected value of the response is $E\left(Y_{i, j}\right)=\mu_{i, j}$ and $\operatorname{var}\left(Y_{i, j}\right)=\mu_{i, j}+\mu_{i, j}^{2} / k$ 
using link function $\mu_{i, j}=\mathrm{e}^{\eta_{i, j}}$. Residual analysis showed a linear relationship indicating a model fit and correct choice of distribution for the data using theta $(k=1.209)$ and with average value of measured distribution $\mu=$ 2.306 .

\section{Results}

\subsection{Stand Level Test of All Natural Regeneration}

The treatments with disc trenching $(\mathrm{HiD})$ had a higher mean density of naturally regenerated seedlings compared to the others $(\operatorname{LoD})(p=0.024)$. In the experiment in Halland the mean density was 19,000 and 15,000 seedlings $\cdot \mathrm{ha}^{-1}$ for HiD and LoD respectively (Figure 2). Corresponding figures for the Kronoberg experiment was lower, 12,000 and 5000 seedlings ha $^{-1}$, respectively. However, the variation between counties and blocks was large although the adjusted R square of Equation (2) was 0.64. By far the most abundant naturally regenerated genus at all blocks was birch. Birch accounted for $63 \%$ and $67 \%$ of all natural regeneration in $\mathrm{HiD}$ and $\mathrm{LoD}$ treatment plots respectively. Of the two species, silver birch was the most common on these mesic sites. The proportion of Silver birch was $85 \%$ and $88 \%$ in Kronoberg and Halland, respectively. At two of the blocks the proportion of silver birch was $67 \%$ but at all other blocks it was $90 \%$ or higher. The next most abundantly naturally regenerated species were Norway spruce (14\% in HiD and $21 \%$ in LoD, respectively) and goat willow (9\% in $\mathrm{HiD}$ and $4 \%$ in LoD, respectively). Species abundance varied between blocks, between $36 \%-84 \%$ for birch, $2 \%-42 \%$ for Norway spruce and $1 \%-49 \%$ for goat willow. Aspen was the only other tree species detected at all blocks but accounted for at most $6 \%$ of the total number of registered seedlings in a block.

\subsection{Sample Plot Level of Birch Regeneration}

The birch regeneration model showed a significant disturbance effect $(p<0.001$, Table 3$)$ although its magnitude depended on the block, the interaction between block and soil disturbance treatment, seed supply and distance from seed source in the individual sample plots. In all blocks the distance to seed sources was strongly negatively correlated with densities of established birch seedlings. The measured counts and the modelled estimates plotted in seedling densities (seedlings $\cdot \mathrm{m}^{-2}$ ) over seed source distance $(\mathrm{m})$ visualized the relation of distance to seed source and soil disturbance (Figure 3). The ratio of sample plots with zero birch seedlings was $50 \%$ for $\mathrm{HiD}$ and $58 \%$ for LoD treatments. The highest seedling counts in sample plots were 30 and 24 in HiD and LoD, respectively.

All other variables included in the model were also significant with $p$-values well below 0.05 (Table 3). Scarification by disc trenching (HiD) not only created larger proportion of bare mineral soil but also changed forest floor structure, described in the model by the functional vegetation groups. Sample plots with high colonisation of raspberry or grasses had significantly lower number of birch seedlings and were more frequently devoid of naturally regenerated birch. Still, the total variance between soil disturbance levels was not large for

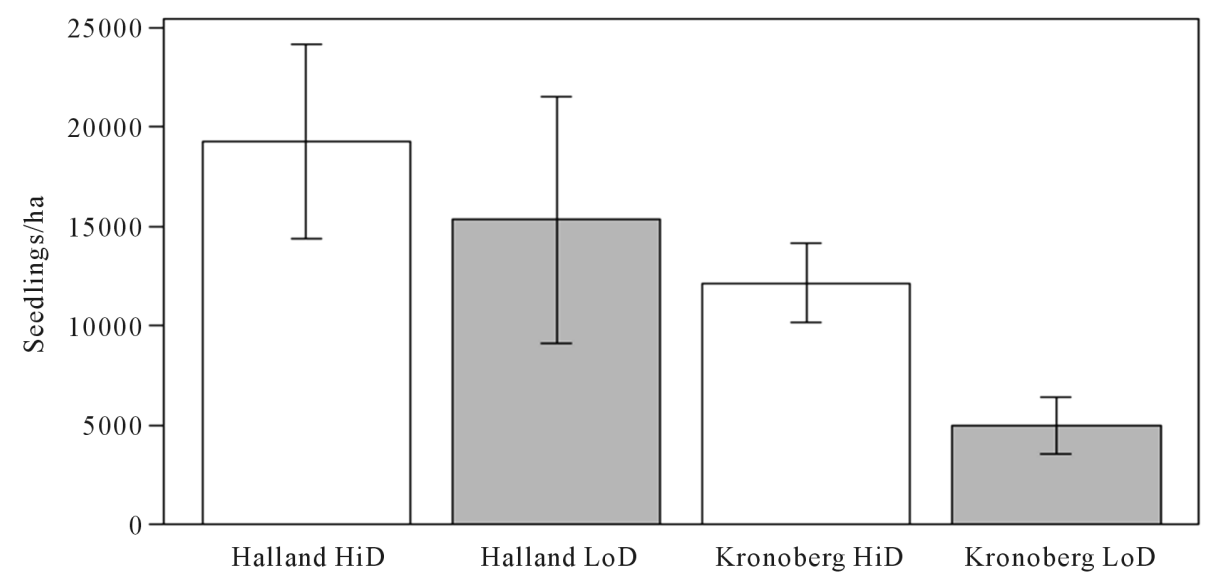

Figure 2. Densities of naturally regenerated seedlings (seedlings $\cdot \mathrm{ha}^{-1}$ ). Average and SE values for $\mathrm{s}$ the treatments with soil disturbance level: LoD = Low Disturbance, HiD $=$ High Disturbance in Halland and Kronoberg. 
Table 3. Birch regeneration model, coefficients, estimates $z$ score and $p$-value. Abbreviations according to model description.

\begin{tabular}{ccccc}
\hline Coefficients & Estimate & Std. Error & $z$ value & $\operatorname{Pr}(>|z|)$ \\
\hline (Intercept) & 0.917 & 0.138 & 6.651 & $<0.001$ \\
Dist & -0.014 & 0.002 & -8.295 & $<0.001$ \\
Moss & 0.647 & 0.071 & 9.092 & $<0.001$ \\
RubOcc & -1.697 & 0.109 & -15.545 & $<0.001$ \\
Grass & -0.265 & 0.104 & -2.561 & 0.010 \\
RegOther & 0.111 & 0.014 & 8.001 & $<0.001$ \\
SoilD(LoD) & -0.625 & 0.174 & -3.598 & $<0.001$ \\
Block2 & -1.076 & 0.106 & -10.190 & $<0.001$ \\
Block3 & -2.129 & 0.157 & -13.606 & $<0.001$ \\
Block4 & 0.019 & 0.101 & 0.184 & 0.854 \\
Block12 & -1.120 & 0.170 & -6.600 & $<0.001$ \\
Block45 & -0.697 & 0.148 & -4.727 & $<0.001$ \\
Block86 & -0.247 & 0.147 & -1.679 & 0.093 \\
LoD:Block2 & 1.128 & 0.233 & 4.835 & $<0.001$ \\
LoD:Block3 & 2.112 & 0.278 & 7.596 & $<0.001$ \\
LoD:Block4 & -1.176 & 0.288 & -4.089 & $<0.001$ \\
LoD:Block12 & 0.393 & 0.330 & 1.191 & 0.234 \\
LoD:Block45 & 0.162 & 0.317 & 0.512 & 0.609 \\
LoD:Block86 & 0.797 & 0.269 & 2.965 & 0.003 \\
\hline
\end{tabular}

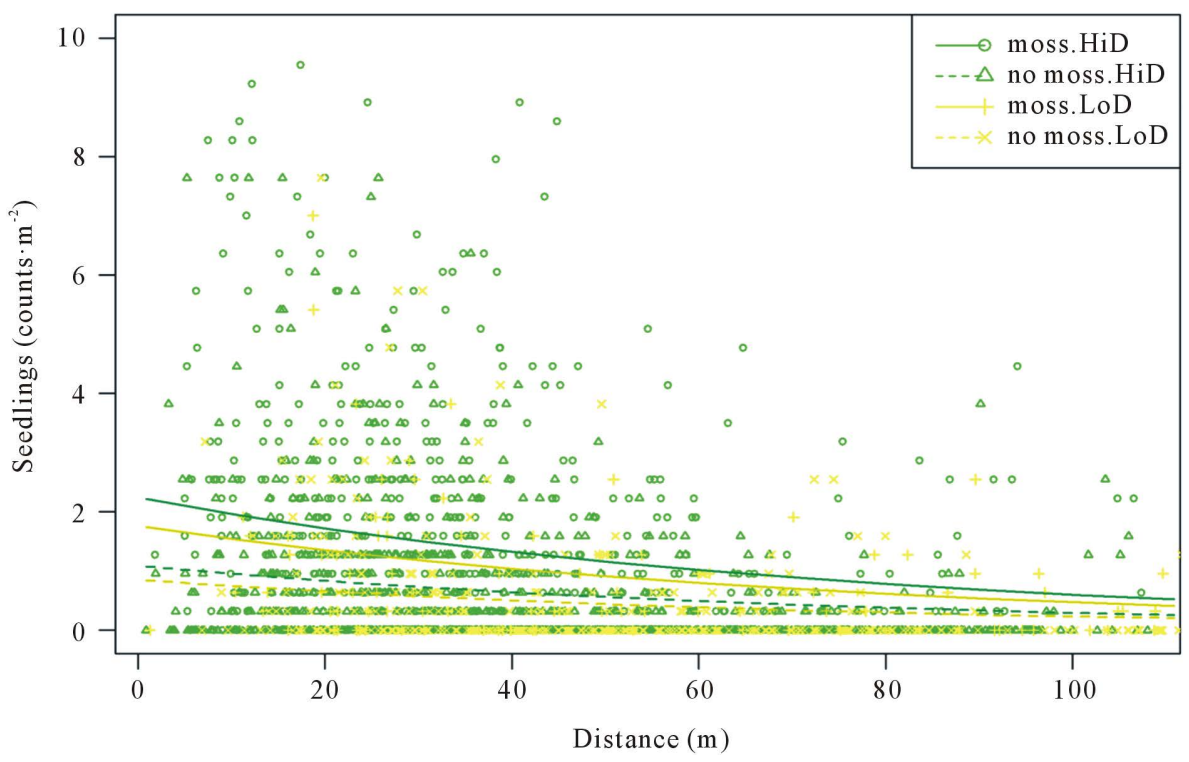

Figure 3. Plotted values of seedling counts $\cdot \mathrm{m}^{-2}$ in measured plots and predicted densities of naturally regenerated birch seedlings $\left(\mathrm{m}^{-2}\right)$ following the Low Disturbance (LoD) and High Disturbance (HiD) treatments in the presence and absence of moss (Moss/No moss) as functions of distance from seed source $(\mathrm{m})$. Six outliers with high values of seedling counts (max distance $50 \mathrm{~m}$ and ranging $10-25$ seedlings $\cdot \mathrm{m}^{-2}$ ) are not shown in the figure. Model prediction (Equation (3)) is visualized by lines according to legend. 
grass coverage (Grassi), for summarized coverage of grasses, herbs and brackens (reduced from the final model) or for the Rubus occupancy (RubOcci) (Figure 4). The indicator mosses used to describe long-term effect of bare mineral soil and scarification-induced-changes in the soil profile were detected in $54 \%$ of the HiD but only in $25 \%$ of the LoD sample plots.

\section{Discussion}

Scarification techniques that expose larger areas of bare mineral soil, like disc trenching in continuous rows, increase the establishment of birch seedlings to densities that might be suitable for establishment of mixed forests. Consistent with earlier studies, the study showed that not only the disturbance rate per se but also the type of scarification affects the regeneration success (Elie et al., 2009; Prevost et al., 2010) and the species composition (Prevosto et al., 2011). However, the scarification effect on a specific site may not be sufficient for predicting the regeneration success. Block and block-treatment interaction did contribute to the regeneration response and this finding was in line with earlier studies (Bataineh et al., 2013; Karlsson, 2001).

Estimating establishment with models or distributions that consider or assess the higher variance and in some parts stochastic or unexplained behavior of natural regeneration has been done in many previous studies (Eerikainen et al., 2007; Messaoud \& Houle, 2006; Miina \& Heinonen, 2008; Olson \& Wagner, 2011; Quero et al., 2011). A major factor influencing treatment responses in this study was the blocking factor, which indicates a large site variation. Supposedly, the differences in stand structure of neighboring stands and the amount of seed supply are important variables explaining this variation. Seed supply was not controlled for a priori in the experiments reported here. The available mature seed trees were registered retrospectively together with GIS measurements of stand boarders and shortest distance to possible seed source. The abundance of seed sources in adjacent stands, retention trees on the clearcuts and refuges of mature broadleaved trees in the nearby surroundings are all potentially important variables, and their specific effects were indirectly included in the blocking factor and the covariate with distance to seed source. Nevertheless, the regeneration success depended on distance to seed source at sample plot level. The relation between seedling counts and seed source distance was similar for both counties and consistent with earlier studies on birch establishment (Fries, 1984; Karlsson, 2001). Effects of the scarification treatment were very weak at distances greater than $60 \mathrm{~m}$ from seed sources, indicating that too
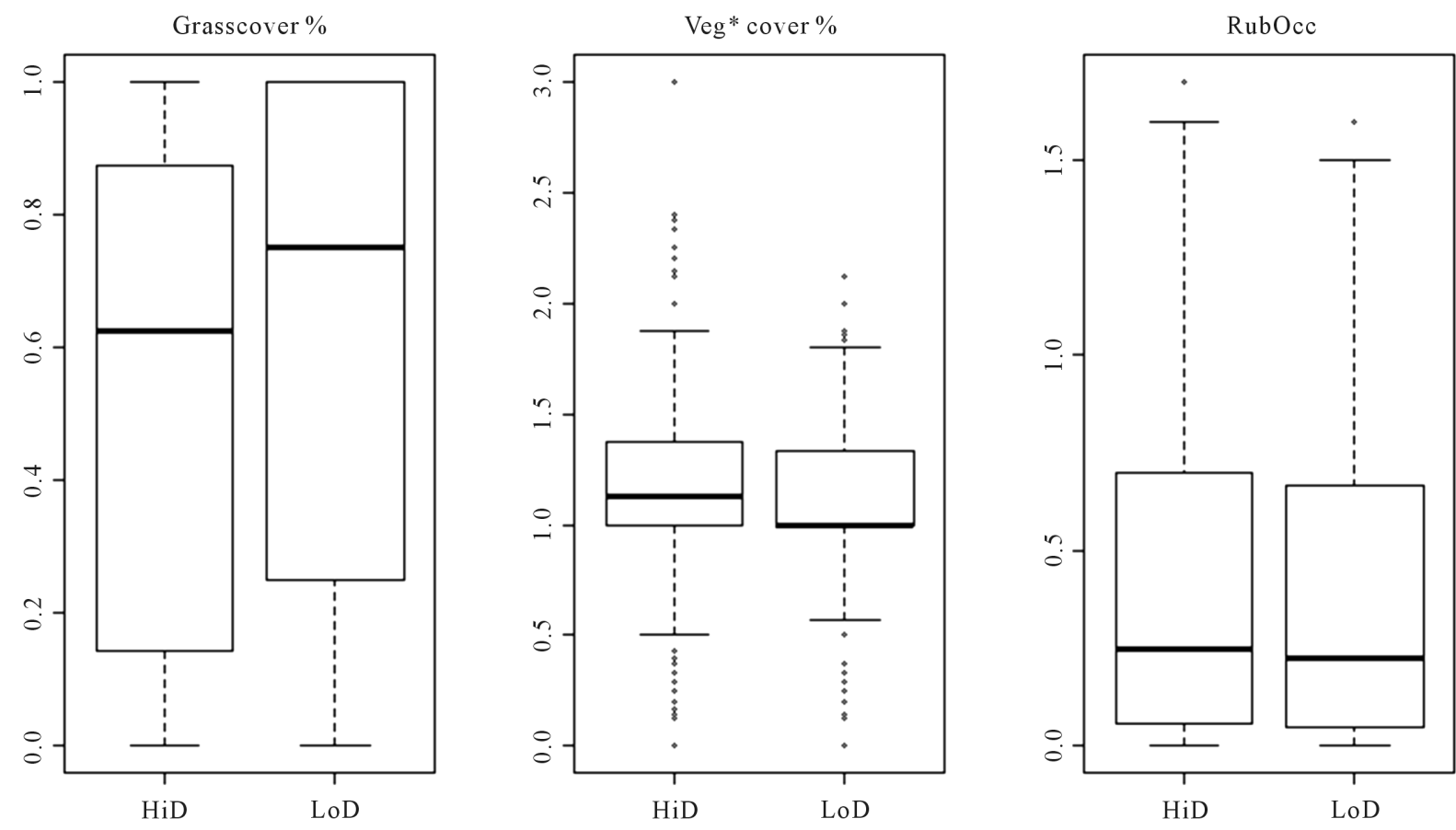

Figure 4. Variance for Grassi, grass cover \%, veg* cover \% and RubOcci, Rubus volume for all plots in disturbance levels $\mathrm{HiD}$ and LoD. Veg* cover is the summarized cover \% for vegetation types: all herbs (including Rubus sp.), brackens and grass. 
few seeds traveled greater distances for adequate natural regeneration. It also indicated that in order to predict and control the tree species mixture and stem density in future stands robustly, the size and shape of clearcuts must be taken into account together with the composition of surrounding stands. Effects of these factors and various PCT options in mixed stands will be further considered, in conjunction with the regeneration data acquired here in the ongoing experiments.

Variations among sites in soil conditions and fertility might affect the regeneration of tree species and their inter-specific competiveness. This is also true for many of the competing grass and herbaceous species (Dodet et al., 2011). This may be one reason why natural regeneration of birch is commonly considered to be more difficult, and thus less preferred, at rich sites (Bergquist et al., 2011). Anomalous scarification effects detected in two blocks ( 2 and 3 ) in Kronoberg may also have been due to rapidly growth of grasses and herbaceous species resulting in a short period of bare mineral soil surfaces (Beland et al., 2000). In the sample plot model high vegetation cover or occupancy of grass (especially wavy hair grass) or raspberry partly explains low number or absence of birch seedlings in sample plots. Both of these competitors respond positively to disturbance after clear cutting (Olsson \& Staaf, 1995; Zobel et al., 2007) and are fast colonizers.

Regional variations in climate conditions and inter-specific differences in responses are also important. For example, variations in soil moisture related to variations in annual and seasonal precipitation may affect seed germination and seedling survival rates on mesic sites and downy birch is more sensitive to drought in the establishment phase than silver birch (Frivold, 1986). This may have explained the lack of birch responses to scarification in some sampling plots, particularly relatively dry plots. The factor Moss is partly correlated to differences in the soil profile, where the lower part in the furrow after disc trenching sometimes have a more moist microhabitat and thereby a more suitable environment for seed germination during a prolongation of time. Sample plots without any of the indicator mosses (Figure 3), showed lower model predictions for both soil disturbance levels. This indicated that with a prolonged timeframe of bare-mineral soil, the seed germination will continue for several years after treatment. However, in a planted stand, the small, late emerging seedlings will probably be out competed by the planted seedlings and earlier naturally regenerated seedlings.

A further confounding factor is the seasonal timing of scarification and its impact on seedling establishment (Karlsson, 2001). In this study the soil was scarified during spring or early summer at all sites, thus variations in its timing should not have affected the results. All clearcuts were made in 2005 after the storm Gudrun. However, the experimental clearcuts in the two counties were not planted and scarified the same year. Eventual increase in the variance of the model due to the timing of experiment establishment was included in the blocking factor and should therefore not have an effect on the outcome of the results. Seedling densities were higher at the Halland sites than the Kronoberg sites, possibly because the former receive twice as much annual precipitation, and higher abundance of birch in the surroundings. In the double disc trenching treatments (HiD) at the experiments in Halland there were lower densities of naturally regenerated birch in the planted treatment plots than in unplanted plots at the same block, probably due to competition from Norway spruce seedlings (planted and/or naturally regenerated), or a shift in vegetation composition, as observed by (Johansson et al., 2013b). Natural regeneration of Norway spruce also responded well to soil scarification, and the relatively weak response from birch could have been due to competition between the tree species since scarification type and soil disturbance level have varying impact on different tree species in the regeneration phase (Mou et al., 1993). However, the covariate with counts of other seedlings than birch was positively significant in the model. Probably the effect of soil scarification and soil moisture content was more important for germination and survival of both birch and other seedlings than the effect of competition between seedlings.

The effects of pine weevil feeding on naturally regenerated seedlings have not been as thoroughly investigated as its effects on planted material. However, it may cause significant damage to broadleaves, and more specifically silver birch (Toivonen \& Viiri, 2006). In this study the effects of pine weevils were not measured, but reductions in the damage they caused may have contributed to the positive effect of bare mineral soil on natural regeneration of birch. More importantly, the impact of browsing ungulates was visual and it is very likely that the abundance and growth of both naturally regenerated seedlings and ground vegetation would have been different if the blocks had been fenced or the population of browsing ungulates had been lower.

In accordance with earlier studies this study show that the application of appropriate management practices can facilitate the control of natural regeneration after clear cutting. Establishing and sustainably maintaining mixed stands to meet shifting demands from industry, landowners and other stakeholders are major challenges for forest planning and management in the Nordic countries. Switching from homogeneous single-species stands 
to multi-species stands is a possible solution. Results from this study indicate that traditional management in the regeneration phase can be sufficient to establish stands with mixtures of Norway spruce and birch. However, further studies should extend the findings and identify suitable protocols for later stages of the rotations.

\section{Acknowledgements}

We would like to thank Ulf Johansson and the staff at Asa and Tönnersjöhedens experimental stations, SLU. We also thank Mikael Andersson Franko, SLU for statistical advice. This paper has been written as part of the interdisciplinary programme Future Forest financed by Mistra (the Foundation for Strategic Environmental Research), the Forestry Research Institute of Sweden (Skogforsk), the Swedish University of Agricultural Sciences (SLU), and Umeå University.

\section{References}

Ammer, S., Weber, K., Abs, C., Ammer, C., \& Prietzel, J. (2006). Factors Influencing the Distribution and Abundance of Earthworm Communities in Pure and Converted Scots Pine Stands. Applied Soil Ecology, 33, 10-21. http://dx.doi.org/10.1016/j.apsoil.2005.09.005

Bataineh, M., Kenefic, L., Weiskittel, A., Wagner, R., \& Brissette, J. (2013). Influence of Partial Harvesting and Site Factors on the Abundance and Composition of Natural Regeneration in the Acadian Forest of Maine, USA. Forest Ecology and Management, 306, 96-106. http://dx.doi.org/10.1016/i.foreco.2013.06.016

Beland, M., Agestam, E., Eko, P. M., Gemmel, P., \& Nilsson, U. (2000). Scarification and Seedfall Affects Natural Regeneration of Scots Pine under Two Shelterwood Densities and a Clear-Cut in Southern Sweden. Scandinavian Journal of Forest Research, 15, 247-255. http://dx.doi.org/10.1080/028275800750015064

Bergquist, J., Eriksson, A., \& Fries, C. (2011). Skogsstyrelsen Polytax 5/7 återväxttaxering: Resultat från 1999-2009 (1100-0295) [Forest Agency Regenerating Inventory 1999-2009]. (In Swedish) http://shop.skogsstyrelsen.se/shop/9098/art14/7439014-ff87fe-1831.pdf

Bergquist, J., Orlander, G., \& Nilsson, U. (1999). Deer Browsing and Slash Removal Affect Field Vegetation on South Swedish Clearcuts. Forest Ecology and Management, 115, 171-182. http://dx.doi.org/10.1016/S0378-1127(98)00397-1

Bravo-Oviedo, A., Pretzsch, H., Ammer, C., Andenmatten, E., Barbati, A., Barreiro, S. et al. (2014). European Mixed Forests: Definition and Research Perspectives. Forest Systems, 23, 518-533. http://dx.doi.org/10.5424/fs/2014233-06256

Carnus, J. M., Parrotta, J., Brockerhoff, E., Arbez, M., Jactel, H., Kremer, A. et al. (2006). Planted Forests and Biodiversity. Journal of Forestry, 104, 65-77.

Chauvat, M., Titsch, D., Zaytsev, A. S., \& Wolters, V. (2011). Changes in Soil Faunal Assemblages during Conversion from Pure to Mixed Forest Stands. Forest Ecology and Management, 262, 317-324. http://dx.doi.org/10.1016/j.foreco.2011.03.037

Clark, C. J., Poulsen, J. R., Levey, D. J., \& Osenberg, C. W. (2007). Are Plant Populations Seed Limited? A Critique and Meta-Analysis of Seed Addition Experiments. American Naturalist, 170, 128-142. http://dx.doi.org/10.1086/518565

Dodet, M., Collet, C., Frochot, H., \& Wehrlen, L. (2011). Tree Regeneration and Plant Species Diversity Responses to Vegetation Control Following a Major Windthrow in Mixed Broadleaved Stands. European Journal of Forest Research, 130, 41-53. http://dx.doi.org/10.1007/s10342-010-0406-z

Eerikainen, K., Miina, J., \& Valkonen, S. (2007). Models for the Regeneration Establishment and the Development of Established Seedlings in Uneven-Aged, Norway Spruce Dominated Forest Stands of Southern Finland. Forest Ecology and Management, 242, 444-461. http://dx.doi.org/10.1016/j.foreco.2007.01.078

Elie, J. G., Ruel, J. C., \& Lussier, J. M. (2009). Effect of Browsing, Seedbed, and Competition on the Development of Yellow Birch Seedlings in High-Graded Stands. Northern Journal of Applied Forestry, 26, 99-105.

Felton, A., Andersson, E., Ventorp, D., \& Lindbladh, M. (2011). A Comparison of Avian Diversity in Spruce Monocultures and Spruce-Birch Polycultures in Southern Sweden. Silva Fennica, 45, 1143-1150. http://dx.doi.org/10.14214/sf.92

Felton, A., Lindbladh, M., Brunet, J., \& Fritz, Ö. (2010). Replacing Coniferous Monocultures with Mixed-Species Production Stands: An Assessment of the Potential Benefits for Forest Biodiversity in Northern Europe. Forest Ecology and Management, 260, 939-947. http://dx.doi.org/10.1016/i.foreco.2010.06.011

Felton, A., Nilsson, U., Sonesson, J., Felton, A., Roberge, J.-M., Ranius, T. et al. (2016). Replacing Monocultures with Mixed-Species Stands: Ecosystem Service Implications of Two Production Forest Alternatives in Sweden. Ambio, 45, 124-139. http://dx.doi.org/10.1007/s13280-015-0749-2

Foley, J. A., DeFries, R., Asner, G. P., Barford, C., Bonan, G., Carpenter, S. R. et al. (2005). Global Consequences of Land Use. Science, 309, 570-574. http://dx.doi.org/10.1126/science.1111772 
Fries, C. (1984). Den frösådda björkens invandring på hygget [glasbjörk, vårtbjörk]. Sveriges Skogsvårdsförbunds Tidskrift, $82,15$.

Frivold, L. H. (1986). Natural Regeneration of Birch and Norway Spruce on Clearfelled Areas in the East Norwegian Lowlands in Relation to Vegetation Type and Moisture. Meddelelser fra Norsk Institutt for Skogforskning, 39, 67-84.

Götmark, F., Fridman, J., Kempe, G., \& Norden, B. (2005). Broadleaved Tree Species in Conifer-Dominated Forestry: Regeneration and Limitation of Saplings in Southern Sweden. Forest Ecology and Management, 214, 142-157. http://dx.doi.org/10.1016/j.foreco.2005.04.001

Granström, A., \& Fries, C. (1985). Depletion of Viable Seeds of Betulapubescens and Betulaverrucosa Sown onto Some North Swedish Forest Soils. Canadian Journal of Forest Research, 15, 1176-1180. http://dx.doi.org/10.1139/x85-191

Greene, D. F., \& Johnson, E. A. (1989). A Model of Wind Dispersal of Winged or Plumed Seeds. Ecology, 70, $339-347$. http://dx.doi.org/10.2307/1937538

Hägglund, B. R. (1977). Site Index Estimation by Means of Site Properties: Scots Pine and Norway Spruce in Sweden (Skattning av höjdboniteten med ståndortsfaktorer: Tall och gran i Sverige). Stockholm: Stockholm: Swedish College Of Forestry.

Hallingbäck, T., \& Tomas, H. (1996). Ekologisk katalog över mossor (Ecological Catalogue of Mosses) (1st ed.). Uppsala: Solna: Uppsala: ArtDatabanken, Sveriges lantbruksuniv. Solna: Naturvårdsverket.

Hallsby, G., \& Orlander, G. (2004). A Comparison of Mounding and Inverting to Establish Norway Spruce on Podzolic Soils in Sweden. Forestry, 77, 107-117. http://dx.doi.org/10.1093/forestry/77.2.107

Hansson, K., Olsson, B. A., Olsson, M., Johansson, U., \& Kleja, D. B. (2011). Differences in Soil Properties in Adjacent Stands of Scots Pine, Norway Spruce and Silver Birch in SW Sweden. Forest Ecology and Management, 262, 522-530. http://dx.doi.org/10.1016/i.foreco.2011.04.021

Hedwall, P.-O., Brunet, J., Nordin, A., \& Bergh, J. (2013). Changes in the Abundance of Keystone Forest Floor Species in Response to Changes of Forest Structure. Journal of Vegetation Science, 24, 296-306. http://dx.doi.org/10.1111/j.1654-1103.2012.01457.x

Hilbe, J. M., \& Joseph, M. H. (2007). Negative Binomial Regression. Cambridge: Cambridge University Press. http://dx.doi.org/10.1017/CBO9780511811852

Ilisson, T., Koester, K., Vodde, F., \& Jogiste, K. (2007). Regeneration Development 4 - 5 Years after a Storm in Norway Spruce Dominated Forests, Estonia. Forest Ecology and Management, 250, 17-24. http://dx.doi.org/10.1016/j.foreco.2007.03.022

Johansson, K., Nilsson, U., \& Örlander, G. (2013a). A Comparison of Long-Term Effects of Scarification Methods on the Establishment of Norway Spruce. Forestry, 86, 91-98.

Johansson, K., Ring, E., \& Hogbom, L. (2013b). Effects of Pre-Harvest Fertilization and Subsequent Soil Scarification on the Growth of Planted Pinus sylvestris Seedlings and Ground Vegetation after Clear-Felling. Silva Fennica, 47, 18.

Karlsson, M. (2001). Natural Regeneration of Broadleaved Tree Species in Southern Sweden-Effects of Silvicultural Treatments and Seed Dispersal from Surrounding Stands. Dissertation, Alnarp: Swedish University of Agricultural Sciences.

Karlsson, M., Nilsson, U., \& Orlander, G. (2002). Natural Regeneration in Clear-Cuts: Effects of Scarification, Slash Removal and Clear-Cut Age. Scandinavian Journal of Forest Research, 17, 131-138. http://dx.doi.org/10.1080/028275802753626773

Knoke, T., Ammer, C., Stimm, B., \& Mosandl, R. (2008). Admixing Broadleaved to Coniferous Tree Species: A Review on Yield, Ecological Stability and Economics. European Journal of Forest Research, 127, 89-101. http://dx.doi.org/10.1007/s10342-007-0186-2

Löf, M. (2000). Influence of Patch Scarification and Insect Herbivory on Growth and Survival in Fagus sylvatica L., Picea abies L. Karst. and Quercus robur L. Seedlings Following a Norway Spruce Forest. Forest Ecology and Management, 134, 111-123.

Löf, M., Dey, D. C., Navarro, R. M., \& Jacobs, D. F. (2012). Mechanical Site Preparation for Forest Restoration. New Forests, 43, 825-848. http://dx.doi.org/10.1007/s11056-012-9332-X

Messaoud, Y., \& Houle, G. (2006). Spatial Patterns of Tree Seedling Establishment and Their Relationship to Environmental Variables in a Cold-Temperate Deciduous Forest of Eastern North America. Plant Ecology, 185, 319-331. http://dx.doi.org/10.1007/s11258-006-9106-7

Miina, J., \& Heinonen, J. (2008). Stochastic Simulation of Forest Regeneration Establishment Using a Multilevel Multivariate Model. Forest Science, 54, 206-219.

Mou, P., Fahey, T. J., \& Hughes, J. W. (1993). Effects of Soil Disturbance on Vegetation Recovery and Nutrient Accumulation Following Whole-Tree Harvest of a Northern Hardwood Ecosystem. Journal of Applied Ecology, 30, 661-675. 
$\underline{\text { http://dx.doi.org/10.2307/2404245 }}$

Munson, A. D., Margolis, H. A., \& Brand, D. G. (1993). Intensive Silvicultural Treatment: Impacts on Soil Fertility and Planted Conifer Response. Soil Science Society of America Journal, 57, 246-255. http://dx.doi.org/10.2136/sssaj1993.03615995005700010043x

Newmaster, S. G., Parker, W. C., Bell, F. W., \& Paterson, J. M. (2007). Effects of Forest Floor Disturbances by Mechanical Site Preparation on Floristic Diversity in a Central Ontario Clearcut. Forest Ecology and Management, 246, $196-207$. http://dx.doi.org/10.1016/j.foreco.2007.03.058

Nilsson, P. (2013). Skogsdata: Aktuella uppgifter om de svenska skogarna från Riksskogstaxeringen. In N. Cory, J. Fridman, \& G. Kempe (Eds.), Forestdata, National Forest Inventory (In Swedish). Umeå: Institutionen för skoglig resurshushållning, Sveriges lantbruksuniversitet.

Nilsson, U., Fahlvik, N., Johansson, U., Lundstrom, A., \& Rosvall, O. (2011). Simulation of the Effect of Intensive Forest Management on Forest Production in Sweden. Forests, 2, 373-393. http://dx.doi.org/10.3390/f2010373

Nilsson, U., Gemmel, P., Johansson, U., Karlsson, M., \& Welander, T. (2002). Natural Regeneration of Norway Spruce, Scots Pine and Birch under Norway Spruce Shelterwoods of Varying Densities on a Mesic-Dry Site in Southern Sweden. Forest Ecology and Management, 161, 133-145. http://dx.doi.org/10.1016/S0378-1127(01)00497-2

Olson, M. G., \& Wagner, R. G. (2011). Factors Affecting Species Richness of Tree Regeneration in Mixed-Wood Stands of Central Maine. Journal of Vegetation Science, 22, 303-311. http://dx.doi.org/10.1111/j.1654-1103.2011.01258.x

Olsson, B. A., \& Staaf, H. (1995). Influence of Harvesting Intensity of Logging Residues on Ground Vegetation in Coniferous Forests. Journal of Applied Ecology, 32, 640-654. http://dx.doi.org/10.2307/2404659

Paré, D., Bernier, P., Thiffault, E., \& Titus, B. D. (2011). The Potential of Forest Biomass as an Energy Supply for Canada. Forestry Chronicle, 87, 71-76. http://dx.doi.org/10.5558/tfc87071-1

Petersson, M., Orlander, G., \& Nordlander, G. (2005). Soil Features Affecting Damage to Conifer Seedlings by the Pine Weevil Hylobius abietis. Forestry, 78, 83-92. http://dx.doi.org/10.1093/forestry/cpi008

Prevost, M., Raymond, P., \& Lussier, J. M. (2010). Regeneration Dynamics after Patch Cutting and Scarification in Yellow Birch-Conifer Stands. Canadian Journal of Forest Research, 40, 357-369. http://dx.doi.org/10.1139/X09-192

Prevosto, B., Bousquet-Melou, A., Ripert, C., \& Fernandez, C. (2011). Effects of Different Site Preparation Treatments on Species Diversity, Composition, and Plant Traits in Pinus halepensis Woodlands. Plant Ecology, 212, 627-638. http://dx.doi.org/10.1007/s11258-010-9852-4

Quero, J. L., Herrero, A., \& Zamora, R. (2011). Linking Stochasticity to Determinism of Woody Plant Recruitment in a Mosaic Landscape: A Spatially Explicit Approach. Basic and Applied Ecology, 12, 161-171.

http://dx.doi.org/10.1016/j.baae.2010.11.007

R Core Team (2013). R: A Language and Environment for Statistical Computing. Vienna, Austria: R Foundation for Statistical Computing. http://www.R-project.org/

Rosén, K., \& Lundmark-Thelin, A. (1987). Increased Nitrogen Leaching under Piles of Slash-A Consequence of Modern Forest Harvesting Techniques. Scandinavian Journal of Forest Research, 2, 21-29. http://dx.doi.org/10.1080/02827588709382443

Spracklen, B. D., Lane, J. V., Spracklen, D. V., Williams, N., \& Kunin, W. E. (2013). Regeneration of Native Broadleaved Species on Clearfelled Conifer Plantations in Upland Britain. Forest Ecology and Management, 310, $204-212$. http://dx.doi.org/10.1016/i.foreco.2013.08.001

Thelin, G., Rosengren, U., Callesen, I., \& Ingerslev, M. (2002). The Nutrient Status of Norway Spruce in Pure and in Mixed-Species Stands. Forest Ecology and Management, 160, 115-125. http://dx.doi.org/10.1016/S0378-1127(01)00464-9

Thiffault, N., \& Roy, V. (2011). Living without Herbicides in Quebec (Canada): Historical Context, Current Strategy, Research and Challenges in Forest Vegetation Management. European Journal of Forest Research, 130, 117-133. http://dx.doi.org/10.1007/s10342-010-0373-4

Toivonen, R., \& Viiri, H. (2006). Adult Large Pine Weevils Hylobius abietis Feed on Silver Birch Betula pendula Even in the Presence of Conifer Seedlings. Agricultural and Forest Entomology, 8, 121-128. http://dx.doi.org/10.1111/j.1461-9563.2006.00290.x

Vodde, F., Jogiste, K., Kubota, Y., Kuuluvainen, T., Koester, K., Lukjanova, A. et al. (2011). The Influence of Storm- Induced Microsites to Tree Regeneration Patterns in Boreal and Hemiboreal Forest. Journal of Forest Research, 16, $155-167$. http://dx.doi.org/10.1007/s10310-011-0273-6

von Oheimb, G., Friedel, A., Bertsch, A., \& Hardtle, W. (2007). The Effects of Windthrow on Plant Species Richness in a Central European Beech Forest. Plant Ecology, 191, 47-65. http://dx.doi.org/10.1007/s11258-006-9213-5

Wallertz, K., \& Petersson, M. (2011). Pine Weevil Damage to Norway Spruce Seedlings: Effects of Nutrient-Loading, Soil 
Inversion and Physical Protection during Seedling Establishment. Agricultural and Forest Entomology, 13, 413-421. http://dx.doi.org/10.1111/j.1461-9563.2011.00536.x

Zobel, M., Kalamees, R., Püssa, K., Roosaluste, E., \& Moora, M. (2007). Soil Seed Bank and Vegetation in Mixed Coniferous Forest Stands with Different Disturbance Regimes. Forest Ecology and Management, 250, 71-76. http://dx.doi.org/10.1016/j.foreco.2007.03.011

Zuur, A. F., Ieno, E. N., \& Elphick, C. S. (2010). A Protocol for Data Exploration to Avoid Common Statistical Problems. Methods in Ecology and Evolution, 1, 3-14. http://dx.doi.org/10.1111/j.2041-210X.2009.00001.x

\section{Submit or recommend next manuscript to SCIRP and we will provide best service for you:}

Accepting pre-submission inquiries through Email, Facebook, Linkedin, Twitter, etc A wide selection of journals (inclusive of 9 subjects, more than 200 journals)

Providing a 24-hour high-quality service

User-friendly online submission system

Fair and swift peer-review system

Efficient typesetting and proofreading procedure

Display of the result of downloads and visits, as well as the number of cited articles

Maximum dissemination of your research work

Submit your manuscript at: http://papersubmission.scirp.org/ 